\title{
研究助成機関とオープンアクセス 一NIHパブリックアクセスポリシーに関して
}

\author{
尾身朝子 ${ }^{1}$, 時実象一 ${ }^{2}$, 山崎 ⿷匚斤 $^{3}$
}

\begin{abstract}
著者抄録 :電子ジャーナルのオープンアクセスの動きは米国の国立衛生研究所 (NIH) の助成研究成 果論文公開の方針で新しい段階を迎えた。NIHは2004年9月に助成研究の成果については, 論文刊行 後6か月以内にNIHの電子ジャーナルサービスPubMed Centralにその最終原稿の電子版を提供し, 無 料公開するように求める提案を行い, 同時に公開意見募集を行った。その結果を受け, 2005年 2 月に 最終方針を発表したが, そこでは出版社の意向を汲 $(く)$ んで論文刊行後 12 か以内に変更された。 この方針は2005年5月2日から実施される。この方針が生まれるに至った経緯や影響を与えた各種運 動, またこの提案・方針に関して関係団体や学会・出版社の意見などを解説した。さらにわが国の 学会出版への影響についても論じた。

キーワード : 電子ジャーナル, オープンアクセス, 国立衛生研究所, NIH, 研究助成, PubMed Central, SPARC, 学術出版, 機関リポジトリ
\end{abstract}

\section{Funding agencies and open access -Development of NIH Public Access Policy}

\author{
OMI Asako ${ }^{1}$, TOKIZANE Soichi ${ }^{2}$, YAMAZAKI Takumi ${ }^{3}$
}

\begin{abstract}
Author Abstract: Open access of electronic journals reached a new stage when the National Institutes of Health (NIH) decided on a Public Access Policy for funded research results recently. In September 2004 they proposed a plan requesting researchers who received NIH research funds to submit their final manuscripts to NIH's PubMed Central within 6 months of publication, to be freely available, and asked for public comments on that plan. After considering those comments NIH announced the final policy in February 2005. That policy differed from the proposal in that the deadline date for submission was extended to 12 months from the original 6 . The policy was to be effective on May 2, 2005. The history, background, and initiatives which contributed to this decision and comments and arguments from related organizations, scholarly societies, and publishers are described. Finally, its implication for society publishers in Japan is discussed.
\end{abstract}

Key words: Electronic journals, open access, National Institutes of Health, NIH, research funding, PubMed Central, SPARC, scholarly publication, institutional repository

\section{1. オープンアクセスの概要}

後に歴史を振り返ってみると, 2004年はひとつ の転換点ともいえる年になるかもしれない。「誰も
が電子ジャーナルに無料でアクセスできるように すること」というオープンアクセスの議論が 2004 年に急速に活発になり,さまざまな動きが一気に 噴出したからである（歴史と全般的な動向につい

\footnotetext{
1 東海大学＼cjkstart総合科学技術研究所（†150-0063 東京都渋谷区富ヶ谷2-28-4）Tel.03-3467-2211 E-mail: omi@new-stage.net

2 愛知大学文学部 図書館情報学専攻（干441-8522 愛知県豊橋市町畑町1-1）Tel.0532-48-0111(7429)

E-mail: tokizane@aichi-u.ac.jp

3 (株)アトラス（テ103-0014 東京都中央区日本橋蚛款町1-39-5水天宮北辰ビル2F） Tel.03-5642-9300

E-mail: yamazaki@atlas.jp

${ }^{1}$ Research Institute of Science and Technology, Tokai University (2-28-4 Tomigaya Shibuya-ku, Tokyo 151-0063)

2 Faculty of Letters, Aichi University (1-1 Machihata-cho Toyohashi-shi, Aichi 441-8522)

${ }^{3}$ Atlas Corporation (Suitengu-Hokushin Bldg 2F, 1-39-5 Nihonbashi Kakigara-cho Chuo-ku, Tokyo 103-0014)
} 
ては1),2),3)参照)。

オープンアクセスという運動が起こったのは, 商業出版社による市場の寡占化が進み，かつ電子 ジャーナルの普及に相まって, 包括契約など, 出 版社主導による価格支配が強まったことに対する 反発からと考えられる。この反発から始まった運 動としてよく知られているのが, 米国の研究図書 館協会 (Association of Research Libraries: ARL) が中 心となって設立したSPARC (Scholarly Publishing and Academic Resources Coalition) である。SPARCは当初 商業出版社に対抗する出版ベンチャーを育てるこ とを方針としたが, これがあまり効果がないこと を知ると, オープンアクセスに大きく舵 (かじ) を とった。SPARCは後述するオープンアクセスに関 する会議・宣言でも大きな役割を果たし, また本 稿の主題である米国国立衛生研究所 $(\mathrm{NIH})$ の計画 でも強力なロビー活動を行っている。

\section{2. オープンアクセスの手段}

\section{1 オープンアクセス雑誌}

オープンアクセスを達成するための手段として は, オープンアクセス雑誌とセルフアーカイブが ある。オープンアクセス雑誌とは, 電子ジャーナ ル論文をまったく無料で公開するもので, その出 版経費は投稿料・掲載料, 寄付, 支援する機関の 会費, 冊子体の販売などで賄うものである。よく 知られているオープンアクセス雑誌にはBioMed Central (BMC) とPublic Library of Science (PLoS) があ るが, そのほかにもNature Publishing Groupその他 で主として投稿料・掲載料モデルによる雑誌が創 刊されている。

すべての論文でなく, 希望があった論文のみを オープンアクセスにする試みもある。一定の掲載 料を払えば，その論文だけを出版後即時に無料公 開するオープンアクセス・オプションと呼ばれる ものである。これはSpringer, Kluwer Academic, Proceedings of the National Academy of Sciences of the United States of America (PNAS), American Institute of Physics (AIP) で試みられている。掲載料はSpringer/ Kluwerが3,000ドル, PNAS が1,000ドル, AIPが2,000 ドルである。最近Blackwell PublishingもOnline Open と呼ばれるオプションを発表したが，これは 2,500 ドルとなっている。

正確にはオープンアクセスとは呼ばれていない が, HighWire Press の雑誌を中心に, 一定期間後は 無料公開するという, いわゆる時差公開も行われ
ている。これは小規模出版社の生き残り策として 注目される。

\section{2. セルフアーカイブと機関リポジトリ}

セルフアーカイブとは, 自分の書いた論文のコ ピーを自分のホームページ, または所属する大学 や研究所のホームページに登載して無料公開する もので, 特に後者を機関リポジトリと呼んでいる。 機関リポジトリについてはまとまった解説4)がある。

機関リポジトリについては, Open Archives Initiative (OAI) のProtocol for Metadata Harvesting $(\mathrm{PMH})$ に準拠したソフトウエアを用いることによ り, 他の機関リポジトリのサーバからメタデータ の収集が可能となる。こうして収集すれば, 理論 的には世界中の機関リポジトリの論文が簡単に検 索できて閲覧できることになる。OAI-PMHに準拠 したソフトウエアとしては, DSpace, GNU Eprints, Open Journal Systemsなどがある。DSpace はマサ チューセッツ工科大学 (MIT) とHewlett-Packardの 共同で開発されたソフトウエアであるが, コーネ ル大学でよく使われているようである。DSpaceの 開発元であるMITの担当者によれば,MITでは機関 リポジトリがあまり積極的に活用されておらず, 学部長を挙げての利用促進を展開中であるとのこ とである。

機関リポジトリを行っている機関のリストとし て,ノッティンガム大学で作成されているDirectory of Open Access Repositories - DOARというものがあ る。

機関リポジトリが最近新たに脚光を浴びたのは, Google Scholarのベータ版が公開されたことによる。 Google Scholar は OCLCの協力により, DSpaceに登 載された論文の全文の索引を開始した。Google Scholarを検索すると, 論文へのリンクとして機関 リポジトリが示されている(図1)。

セルフアーカイブまたは機関リポジトリを実行 するには, 著作権を保有している出版社の許諾が必 要である。最近多くの出版社が基本的にセルフアー カイブ,および所属機関へのリポジトリを認めてい る。許諾手続きなしでリポジトリが可能な出版社も 多い。例えば Elsevier は論文出版後直ちに無許諾で 最終原稿のセルフアーカイブ (機関リポジトリ)を 認めている。ただし, 雑誌本誌のホームページへの リンクを求めている。出版社によっては最終原稿で なく, 発行論文のPDFの登載を認めているところも ある。これら許諾状況の一覧はPublisher copyright policies \& self-archivingに掲載されている。 


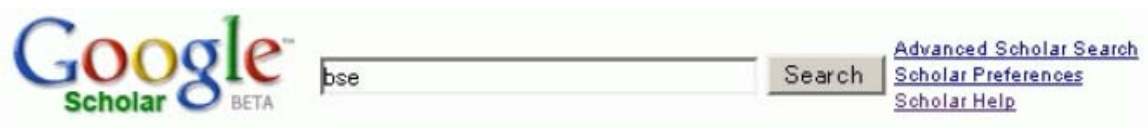

Scholar

Results $\mathbf{1}$ - $\mathbf{1 0}$ of about $\mathbf{5 1 , 9 0 0}$ for bse [definition]. (0.06 seconds)

Transmissions to mice indicate that 'new variant' CJD is caused by the BSE agent

ME Bruce, RG Will, JW Ironside, I McConnell, D ... - Cited by 443 - Web Search

... 7. Foster, JD, Bruce, M. McConnell, I. Chree, A. \& Fraser, H. Detection of BSE

infectivity in brain and spleen of experimentally infected sheep. Vet. Rec. ...

Nature, 1997 - nature.com - ncbi.nlm.nih. gov - ncbi.nlm.nih.gov - csa.com - all 5 versions

\section{Prion diseases and the BSE crisis}

SB Prusiner - Cited by 280 - Web Search

... Note: Due to the interest in this article, Science is offering its readers free

access to the full text. Prion Diseases and the BSE enss. Stanley B.PTusinek

Science, 1997 - dx. doi. org - sciencemag. org hal. bsd.uchicago edu - utoronto.ca all 5 versions

Transmission of BSE by blood transfusion in sheep

F Houston, JD Foster, A Chong, N Hunter, CJ... - Cited by 162 - Web Search

... Click here to read Transmission of BSE by blood transfusion in sheep. Houston

F, Foster JD, Chong A, Hunter N, Bostock CJ. We have ...

Lancet, 2000 - ncbi.nlm. nih. gov - ncbi.nlm. nih. gov

図1 Google Scholar で表示される機関リポジトリ

hal.bsd.uchicago.edu をクリックすると PDF が開く

\section{3. オープンアクセスに関する宣言等}

オープンアクセスを推進するため,これまでに さまざまな会議が開かれ, 宣言が出された。主な ものは表 1のものである。これらは後述の NIH の 計画に大きな影響を与えているので少し説明した い。

\section{1 ブタペスト運動 Budapest Open Access Initiative (BOAI)}

これは2001 年12月1-2日にGeorge Sorosが設立し たOpen Society Instituteの主催で開かれたオープン アクセスについての会議に基づいて起草された宣 言で, 2002年2月14日に発表された。起草者はPLoS のMichael Eisen, SPARCのRick Johnson, サザンプト ン大学のSteven Harnard, アールハム大学のPeter Suber, BioMed CentralのJan Velteropなどで, 3,636人 と304機関が署名している（2005.3.6現在）。その要 点は, まずオープンアクセスとは “free availability on the public internet, permitting any users to read, download, copy, distribute, print, search, or link to the full texts of these articles, crawl them for indexing, pass them as data to software, or use them for any other lawful purpose, without financial, legal, or technical barriers other than those inseparable from gaining access to the internet itself” であると定義している。 次にこれを実現するための手段として, Open Archives Initiative に準拠した「セルフアーカイブ」 と「オープンアクセス雑誌」を提案している。こ こで定義している「オープンアクセス雑誌」とは 購読料やアクセス料を徵収しない雑誌で, 寄付, 研究機関の支援, 投稿料, その他の収入で運営す るとされている。

\section{2 ベセスダ宣言 (Bethesda Statement on Open Access Publishing)}

2003年4月11日に米国メリーランド州のベセスダ で開かれたオープンアクセスに関する会議で起草 された宣言で，6月20日に発表された。参加者には ブタペスト会議に参加したRick Johnson, Peter Suber, Jan Velteropなどのほか, PLoS のHarold Varmus (1989年のノーベル医学賞受賞者で元NIH所

表1 オープンアクセスに関する主な宣言

\begin{tabular}{|l|l|l|}
\hline ブタペスト運動 & 2002.2.14 & http://www.soros.org/openaccess/ \\
\hline ベセスダ宣言 & 2003.6.20 & http://www.earlham.edu/ peters/fos/bethesda.htm \\
\hline ベルリン宣言 & 2003.10.10-22 & http://www.zim.mpg.de/openaccess-berlin/berlindeclaration.html \\
\hline
\end{tabular}


長), NIH のNational Center for Biotechnology Information (NCBI) 所長のDavid Lipman, 英国 Wellcome財団所長のMark J. Walport, Rockfeller財団 のAnthony So, Max-Planck研究所のRobert Schloegl や, 既存出版者側からAmerican Society for Cell Biology, BMJ Publishing, EBMOなども見える。 ここではオープンアクセスを次のように定義し ている。

1. 著者と著作権者が, 利用者による無料でアク セス, 複写, 利用, 流通などを許可すること

2. 完全な論文の版を大学・研究所, 学会, 政府 機関などのリポジトリに保存し提供すること とし, 生医学分野のリポジトリとして PubMed Centralを推奨している。これが後のNIHポリシー の萌（ほう）芽となっている。

さらにこの宣言では,「研究機関・助成機関の宣 言」が書かれていることが注目される。すなわち， 研究機関・助成機関は所属する, または資金を受 ける研究者がオープンアクセスに協力するよう推 進し, オープンアクセスにかかる出版経費を負担 し, また研究評価は論文の出版された雑誌ではな く, 論文そのものによること, オープンアクセス に対する寄与を研究者評価の対象とすることなど を述べている。

さらに「図書館・出版者の宣言」では, 図書館 はオープンアクセスに対応し支援し, オープンア クセス出版とオープンアクセス雑誌の利益を宣伝 し, オープンアクセス雑誌をカタログなどで明示 すること, 出版者はオープンアクセス・オプショ ンを提供し, オープンアクセス・モデルへの移行 計画を明示し, アーカイブに適した電子論文作成 のツールを開発し，さらに投稿料採用の場合は開 発途上国への配慮を行う，などと書かれている。

「科学者・科学界の宣言」では科学者はオープン アクセス・モデルを支持し, 出版のコストは研究 費の欠かせない一部であることを認識し, すべて の論文をオープンアクセスにすべく努力すること， オープンアクセス雑誌ないしはオープンアクセス を目指す雑誌に投稿すること, 研究評価は論文の 載った雑誌ではなく, 論文そのものによるべきで あること,オープンアクセスについての教育を強 化すること，が述べられている。

\section{3 ベルリン宣言 (Berlin Declaration on Open Access to Knowledge in the Sciences and Humanities)}

2003年10月20-22日にベルリンでMax Planck協会
などが中心となってConference on Open Access to Knowledge in the Sciences and Humanitiesが開かれ オープンアクセスについて討議が行われた。この 会合で作成された宣言の特徵は, 研究機関・助成 機関がオープンアクセスを推進するとの内容で, 欧州の研究機関・助成機関の代表が同日, または 後に署名している。すなわち,ドイツのMax Planck 協会会長のPeter Gruss, Fraunhofer協会のHans-Jörg Bullinger, フランスCNRS (Centre National de la Recherche Scientifique: 国立科学研究センター)所長 の Bernard Larrouturou, INSERM (Institut National del la Sante et de la Recherche Medicale: フランス国立保 険医学研究所) 所長のChristian Bréchot, 中国科学研 究院所長のLu Yongxiang, CERN (Conseil European pour la Recherch Nucleaire: 欧州原子核研究機構) の Robert Aymar, パスッール研究所所長のPhilippe Kourilskyなどである。この宣言のオープンアクセ スの定義はべセスダ宣言の定義をそのまま踏襲し ている。オープンアクセスを推進する具体的な方 策としては,研究者にオープンアクセス指針にのっ とった出版を推奨する, 過去分を保有している機 関にオープンアクセス提供を推奨する, オープン アクセス論文の品質を保つための方策を開発する, オープンアクセス論文が研究者評価に用いられる よう推進する，オープンアクセスを支援するツー ルなどの開発を支援する,などが述べられている。 米国物理学会, BioMed Central, EMBO, Swets Blackwell, Wiley, BioOneなどの出版者も参加して いるが, 署名はしていない。

なおべルリン会議は第2回が2004年5月12-13日に ジュネーブのCERNで行われ, 第3回が2005年2月 28 日-3月1日に英国サザンプトン大学で開かれ,オー プンアクセスの議論が行われた。第3回の会議の結 果, 研究機関・助成機関は 1) 研究者が研究論文を オープンアクセス・リポジトリに提供させる方針 をとる, 2) 適切なオープンアクセス雑誌が存在す る場合, 研究者はそこに投稿するよう推奨する, という勧告を出した。

\section{NIHプロポーザルからNIHポリシーヘ}

2004 年5 月には米国国立衛生研究所 (National Institute of Health: NIH)の国立医学図書館 (National Library of Medicine: NLM) が, NIHが資金提供した 研究成果論文をPubMed Centralで無料公開すること を勧告した。これは明らかに前述の2003年6月に発 表されたべセスダ宣言に基づいている。これを受 
けて, 米国下院歳出委員会は7月22日に「連邦納税 者のアクセス提案」(Federal Taxpayer-Access Proposal) を発表した。そこではNIHが資金提供し ている研究成果が2005年以降無料でPubMed Central で公開されるような措置をとるよう要求した。NIH は12月1日までに対策を報告することを求められ た。これに基づき，国立医学図書館 (NLM) は9月3 日にこの件についての案 (NIHプロポーザル)を公 開し，意見を公開募集した ${ }^{5)}$ 。この案は，NIHの助 成を受けた研究についてはその論文が公開されて から6か月以内にPubMed Centralにその論文の最終 原稿を登載することを依頼する,というものであっ た。なお当初は「必要 (required)」という語句が用 いられていたが，9月3日の案で「依頼 (requested)」 ということばに変わった。前者は義務的 (mandatory) な意味があったが, 後者は任意 (voluntary) の意味 なので, 強制力がやや薄まったと考えられる。

以上の一連の動きには前述のSPARCが大きな役 割を果たしている。実際SPARCのRick Johnson は PubMed Centralの諮問委員会のメンバーであった。 SPARCが中心となって設立した「納税者のアクセ スのための協力 (The Alliance for Taxpayer Access)」 は, 図書館や一部の学会も巻き込んで, 国の助成 研究は納税者に対して公開されるべきだとしてこ のプロポーザルを支援した。

この意見募集は当初60日間の予定であったが, 延長され,11月16日に締め切られた。これには6,000 件以上の意見が寄せられたとされている。その内 訳は図2，図3のとおりである。

主な意見は表2のとおりである。

これら意見を踏まえたうえ,2005年2月3日にNIH はいわゆるNIH ポリシー（正式にはPolicy on Enhancing Public Access to Archived Publications Resulting from NIH-Funded Research (蓄積された NIHの助成研究の成果発表に対する公衆のアクセ ス促進に関する政策), 通称NIH Public Access Policy) を発表した6)。これの要旨は次のとおりである。

1)2005年5月 2 日以降, NIHの研究助成を受けた研 究者はNIH国立医学図書館 (NLM) のPubMed Central (PMC) に, 助成研究にかかわる著者の採択済み最 終原稿の電子版を提出することを要求される。

2)この目的は, NIH助成研究から生じた査読済 み論文のアーカイブを作成し，これらを研究者が 活用することによって研究を支援し，NIHの研究 成果論文を公衆, 医学関係者, 教育関係者と科学 者が容易にアクセスできるようにすることである。

3) 2004年9月3日の案との最大の違いは, 当初提

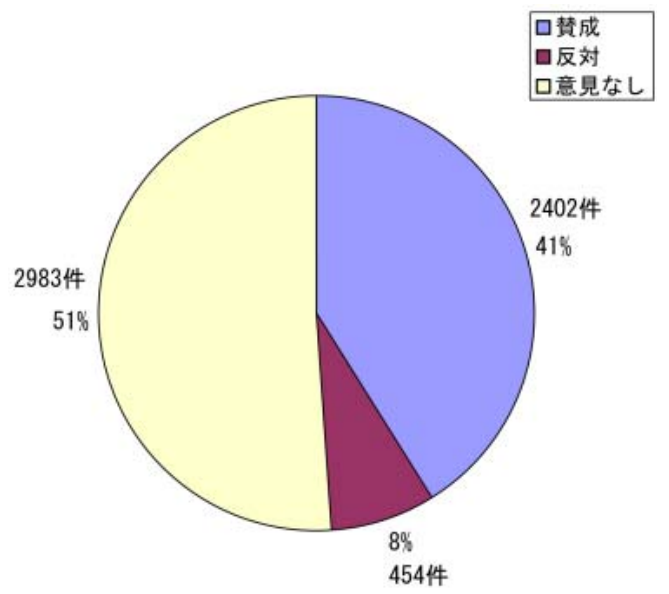

図2 NIH 提案の考え方についての賛否

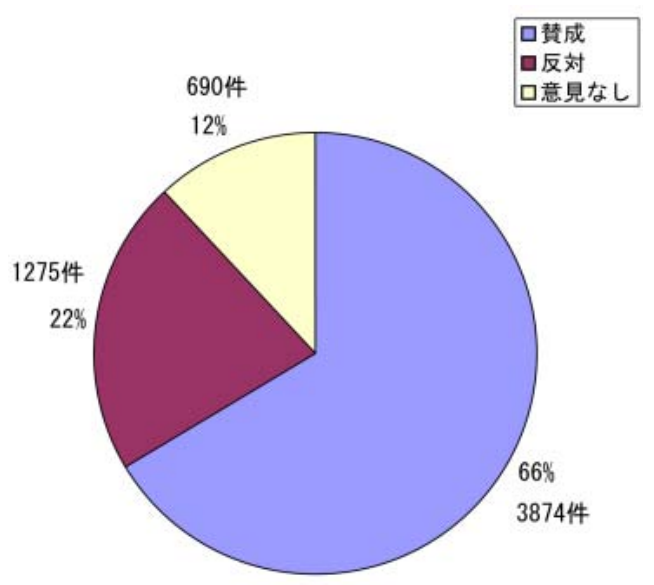

図3 NIH 提案の実行方法についての賛否

出期限が出版後6か月以内とされていたが, 最終的 には 12 用以内できるだけ早くということになっ た。

なお，この文書中では先の公開意見募集におけ る反対意見に対する回答も示されている。例えば 雑誌発行への影響については, 今回対象となる論 文数はPubMed全体の論文の10\%に過ぎず，NIH助 成研究論文が雑誌論文の半数以上となる雑誌は $1 \%$ しかない。したがって図書館がこのために雑誌を キャンセルするおそれは小さいとしている。さら に出版者の声に答えて提出期限を見直したことに 触れ，今後の運用状況を踏まえてさらに出版者と の対話を続けると述べている。また著作権につい ては，NIHは著者に提出を強制しているわけでは ないので著者の自由意思で公開するものであると している。

この計画は一種の機関リポジトリということが 
表2 NHIの提案に対する主な意見

\begin{tabular}{|c|c|}
\hline 賛成 & 反対 \\
\hline $\begin{array}{l}\text { ·納税者は研究結果にアクセスできるべきである } \\
\text { ·情報へのアクセスがよくなれば研究の成果の利用が強 } \\
\text { 化され広がる } \\
\cdot \text { この方針は健康増進に役立つ } \\
\cdot \text { この方針は情報へのアクセスを向上させる } \\
\text { この方針は豊かでない個人・機関・国に平等なアクセ } \\
\text { スを提供する } \\
\text { ·情報へのオンラインアクセスはより安価で入手が容易 } \\
\text { である } \\
\text { · 納税者は出版者のビジネスモデルには責任がない } \\
\text { ·提案は適切な妥協点を示している } \\
\text { • この方針がなければ, 政府が納税者の費用で出版者を } \\
\text { 養うことになる } \\
\text { この方針は研究者としての自分の業績をより見えるよ } \\
\text { うにしてくれる }\end{array}$ & 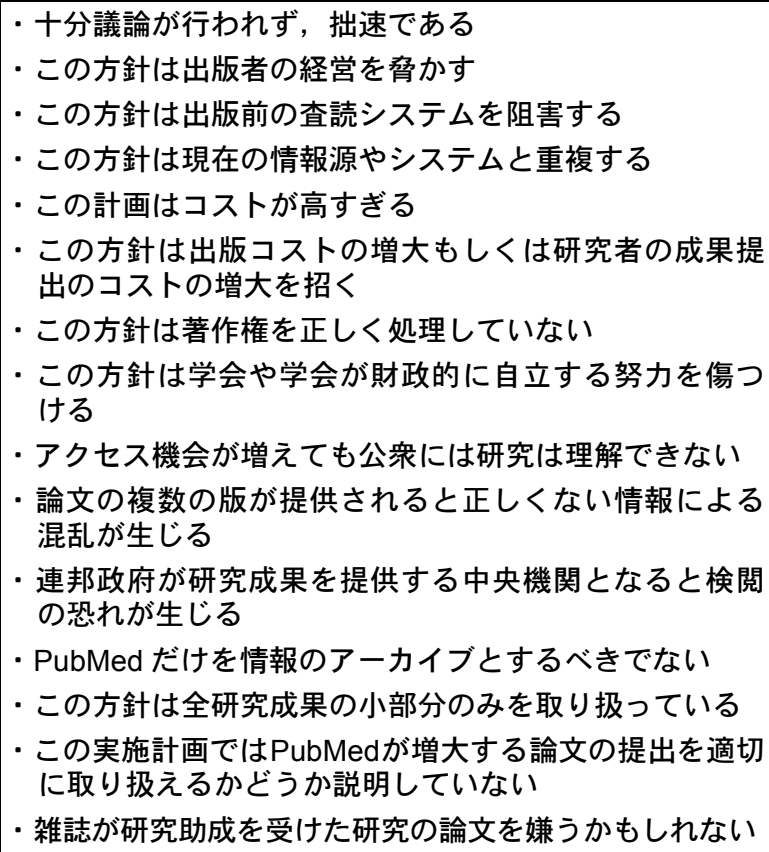 \\
\hline \multicolumn{2}{|r|}{ 質問 } \\
\hline $\begin{array}{l}\cdot \text { ·査読システムの質は低下しないか } \\
\text { ·科学出版に悪い影響はないか } \\
\cdot \text { ·著者や雑誌は著作権を主張できるか } \\
\cdot \text { なぜ PubMed Central なのか } \\
\text { ·実施の費用はいくらか? }\end{array}$ & \\
\hline
\end{tabular}

できる。その目的は1) NIH助成による研究成果を 無料で広く公開する, 2)研究成果論文の安定した アーカイブを維持する, という点にある。ただし, 現時点ではOAI-PMH準拠ソフトウエアが用いられ るのかどうかについては明らかにされていない。

この決定はChicago Tribune (“NIH approves free access to publicly funded studies", 2005.2.10) ${ }^{7)}$, San Francisco Chronicle ("NIH-funded research to be available free", 2005.2.4) ${ }^{8)}$, Washington Post ("NIH Grant Recipients Are 'Asked' to Post Data”, 2005.2.4) ${ }^{9)}$ やEconomist (“Science for Free”, 2005.2.10) 10)などの マスコミでも取り上げられ, 大きな話題となった。 NIHの助成を受けている研究論文の数は年間 60,000 〜65,000件と言われており, PubMedに収録されて いる生医学文献数の $10 \%$ 超えている。これらの 論文全文が1年後, かつ最終原稿の形とはいえ, 無 料公開される影響は多大なものがある。

\section{NIHポリシーについてのさまざまな 立場の意見}

\section{1. 図書館等の意見}

\subsubsection{SPARC}

NIHプロポーザルの推進者であるSPARCは, 当 初の6か月以内という案が12か月に延びたこと, お よびrequiredでなく requestedになったことを批判し つつも, 少なくとも最初の一歩であるとの位置付 けで, ホームページに研究者へのガイドを掲載し ている11)。SPARCのRick Johnsonはこの計画の実施 の成果について「12月に議会に報告するように」 との働きかけをしているということである。これ によりNIHに圧力をかけるとともに, 実施状況に よってはさらに進んだ方針を打ち出させようとす るものである。

5.1.2. 米国医学図書館協会 (Medical Library Association)

6か月が12か月となったことは不満であるという コメントを発表している (2005.2.11) ${ }^{12)}$ 。 


\section{2. 主要学会出版者の意見}

\subsection{1.米国化学会 (ACS)}

2004 年 9 月末にACS のChemical \& Engineering Newsの編集長Rudy M. Baumは既存の学術情報流通 に打撃を与えるものと強い懸念を示したうえで, オープンアクセスの動きは一種の研究の社会主義 化であるとまで述べている13)。この意見に対して は，同じACSの雑誌Biochemistry の編集長である Richard N. Armstrongから，オープンアクセスは時 代のひとつの流れであり, ACSは新しいビジネス モデルの検討も含めてオープンアクセスの議論に 積極的に参加すべきだとの意見が出された ${ }^{14)}$ 。

NIHの方針が出された後,2005年3月7日には, ACS はこれに協力し, 助成を受けた研究の論文が出版 されてから 1 年後にACSの手でPubMed Centralに提 供することを発表した ${ }^{15)}$ 。なお，従来著者の論文 のPDFのダウンロード回数が50回に制限されてい たのを, 無制限とすることを同時に発表している。

5.2.2. 米国物理学協会 (American Institute of

Physics: AIP)

AIPは2004年11月15日にAuthor Selectというオー プンアクセスオプションを発表した16)。これは著 者が 2,000 ドル払えば論文を無料公開するというも ので, Journal of Mathematical Physics, Review of Scientific Instruments, Chaos: An Interdisciplinary Journal of Nonlinear Scienceが対象である。2005年1 月から実施する。NIHの提案についての意見は出 されていない。

\subsubsection{National Academy of Sciences (NAS)}

NASはNIHの提案が出て間もなく, 2004年9月 16 日にこれを支持する声明を評議会 (Council) の名前

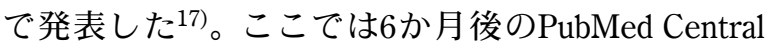
での公開は, 自分のProceedings of the National Academy of Sciences (PNAS) も含め, 雑誌購読に影 響はないので適切な提案であるとしている。また 最終原稿でなく，出版された正式論文のコピーを 載せるべきだとしている。

PNASはこれまでに既にPubMed Centralで6か月過 ぎた論文を無料公開している実績がある。また2004 年5月には，著者が 1,000 ドルを支払うことにより， 論文単位でオープンアクセスとなるOpen Access Optionを発表している18)。NASによれば, 著者の16 \%がオープンアセスオプションを利用しており， 出版後最初の 6 か月で見ると, オープンアクセス 論文はそれ以外の論文に比べ51\%多く読まれてい るという統計が出ている。

\section{3. 小規模学会の意見}

スタンフォード大学図書館のプロジェクト HighWire Pressには多くの小規模学会出版者が電子 ジャーナルを登載している。これらを中心とする 学会が2004年3月16日にワシントンD.C.で会合を開 き「科学のフリーアクセスに関するワシントンD.C. 原則」を発表した。その原則は次のとおりである。

- 情報フィルターとしての学術雑誌を推進

- 収入は科学の発展に用いる

- フリーアクセスの原則

- オンライン雑誌の保存の努力

- 著者, 査読者, 編集者の作業の効率化

- 投稿料・掲載料のみに依存することに反対

- 複数の出版モデルの共存

上記のうち特に「フリーアクセスの原則」とは， 重要な論文は直ちに無料公開する,すべての論文 を直ちに，または数か月後に無料公開する，低所 得国にはすべて無料公開する, 参加雑誌間ではリ ンクを通じての閲覧無料を実施, 主要な検索エン ジンに索引させる, となっている。

これら学会は, 既にHighWire PressにおいてNIH の提案のフリーアクセスの条件は満たしていると して, NIHの計画には批判的であった。NIHの最終 的な計画に対して,これは税金の無駄遣いである という批判を発表している19)。HighWireのMichael A. Kellerによれば，無料公開されている論文数は 828,000以上もある。さらにHighWire内のリンクを 通じて無料公開される論文数はこれに加えて 389,000件あり, 合わせてNIHが計画している数字 よりはるかに大きい。

\section{4 商業出版社の意見}

\subsubsection{Elsevier}

世界最大の商業出版社Elsevierは既に2004年6月 に著者が最終原稿を直ちに自分または所属機関の Webサイトに登載することを認めている。許可は 必要でないが, 雑誌のホームページへのリンクが 必要である。NIHの提案に対してはElsevierは2004 年11月に意見を公開している20)。そこではPubMed Centralへの登載には反対していないが, 論文出版 後1年間は公開を強要すべきではなく,またPubMed Centralの最終原稿から正式論文へのリンクをつけ ることを要望している。

\subsubsection{Nature Publishing Group (NPG)}

Nature Publishing Groupは2005年1月10日に「自己 機関のアーカイブのみを認めていた」従来の方針 を変更して,論文発行後6か月たったら研究助成機 
関のアーカイブに最終原稿の登載を認めることを 発表した21)。

なお NPG は2005 年春から欧州分子生物機構 (European Molecular Biology Organization: EMBO) と 協力して投稿料を基礎とするオープンアクセスの 新雑誌Molecular Systems Biologyを創刊することに なっている22)。

\subsubsection{Science Magazine}

Scienceは著者が最終原稿を自分のWebサイトに 登載することを認めている23)。これはScience上の 論文にリンクを張ることが条件である。なお，自 分のWebサイトには所属機関 (非営利機関に限る) のWebサイトも含まれるので, 機関リポジトリが 含まれることになる。NIHの方針についてはまだ 公の態度表明はないようである。

5.4.4. 米国出版者協会 (Association of American Publishers)

米国出版者協会は批判的なコメントを発表して いる24)。

\section{6. その他の動き}

英国下院の科学技術委員会は2003年から科学技 術雑誌の価格高騰の問題の議論を始め, 2004年3-5 月には, Blackwell, Nature, Wiley, Reed Elsevier, 英 国物理学会, 学術職能団体出版者協会 (ALPSP), Oxford University Press, Axiope Project, BioMed Central,PLoS, 英国図書館, ケンブリッジ大学,JIST, そのほかの証言もしくは証拠提出を依頼した。そ の議論の結果7月7日付けで「科学出版, 誰にでも 無料?」 ${ }^{25)}$ と題した報告書を発表した。この報告書 では，まず商業出版社の現在の価格政策は高額か つ不透明であり，その包括契約方式は好ましくな く, 図書館の困難を招いていること, この状態を 解決するため, 英国政府が機関リポジトリを支援 し, 英国で行われた研究成果を無料で公開するこ と, 厳密な査読・審査システムが重要であること, 投稿料モデルはすでに一定の範囲で確立したと思 われるが, 学会出版への影響や「ただ乗り」の問 題もありさらに検討が必要なこと, 国際的な協力 が必要なこと,などを勧告している。

これに対して政府貿易産業省が報告書に対して 当面施策の必要はなしと回答した (2004.10.26) ${ }^{26)}$ 。 すると科学技術委員会はただちに反論し (2004.11.8), 政府の回答は科学技術委員会が推奨し ていない「著者負担」に焦点を当て, 論点をぼか していると主張した ${ }^{27)}$ この反論については政府
が再回答している $(2005.1 .18)^{28)}$ 。

一方英国で生医学分野最大の研究助成機関 Wellcome財団は, 科学技術委員会の報告書が出る とすぐにこれに賛意を表明した (2004.7.20) 29)。 Wellcomeは研究成果がopen public archival repository で公開されることを推進しており，今年の 3 月に は「Wellcomeのファンドを受けている研究者は出 版後 6 か月以内にUK PubMed Centralに電子原稿を デポジットすることを義務付ける」方針を発表し た (2005.3.15) ${ }^{30)}$ 。こ水に先立って英国版PubMed Central（UKPMC）の設立に向けてPubMed Central と協議を始めている(2004.11.4) ${ }^{31)}$ 。さらに, Wellcome 財団は医学雑誌の過去分のアーカイブ化をPubMed Centralと協力して進めている ${ }^{32) 。}$

また, 世界最大の素粒子物理学研究施設である 欧州原子核研究機構 (CERN) は2005年3月31日に理 事会がオープンアクセスの方針を支持することを 決定した。これによれば，CERNは2月にサザンプ トンで開かれたベルリン宣言第3回会議の勧告を支 持し, 研究者にオープンアクセスのリポジトリヘ の論文の提供と, オープンアクセス雑誌への投稿 を推奨することを明言している ${ }^{33)}$ 。この動きは他 の研究機関・研究助成機関への影響があると思わ れる。

\section{7. わが国への影響}

\section{1 わが国の研究助成機関への影響}

NIHの今回の計画は世界中の研究助成機関が注 目している。研究助成機関としては, 自分が助成 した研究成果をアーカイブすることは,

1) 助成機関の活動の説明責任を果たすことがで きる

2) 助成活動と助成研究の評価が容易になる

3) 助成研究の恒久的保存ができる

という点で魅力的である。わが国の研究助成機関, 例えば科学技術振興機構や民間の助成機関も検討 を行っていると思われる。

\section{2 学協会への影響}

NIHの計画はわが国の学協会にも影響が及ぶ可 能性がある。NIHの助成を一部でも受けた研究の 論文は, 世界のどこの雑誌に発表されようとも PubMed Centralへの提供を求められる。日本の研究 者でも直接, または米国留学の際などに間接的に NIHの助成を受けている可能性がある (NIHの助成 はカナダ, 欧州, アジアなどの大学・研究機関に 
対しても行われている。ただし，2004年に関して は日本の大学・研究機関の名前は見当たらなかっ た)。日本の学協会がNIHへの論文提供を許諾しな い場合には, 研究者はその雑誌への投稿を控えざ るを得ない。

したがって, わが国の学協会も, NIHの計画に 対する方針, さらにはそのほかのセルフアーカイ ブに対する方針を決める必要がある。その場合は, 1) NIHを含むセルフアーカイブへの論文の登載を 認めるか, 2) もし認めるなら最終原稿に限るか, 雑誌に発表された正式論文のPDFも許すか, 3) も し認めるなら, 論文発行後何か月たってから許す か, などを決める必要がある。最終原稿に限った 場合は，正式な論文との差別化が可能となるが， ページなどが振られていない原稿では引用が限ら れ，インパクトファクターにも悪影響がある可能 性がある。積極的にセルフアーカイブを認めるこ とで，よい論文を集めるという戦略も考えられる。

このような方針を決めるには, セルフアーカイ ブを許した場合のビジネスモデルの検討も必要と なる。現時点では, セルフアーカイブならびにオー プンアクセスがわが国の学協会の経営にどのよう な影響を与えるかは予断を許さないが, 半年, も しくは1年後にセルフアーカイブで無料公開される とすれば, 過去分の閲覧にはすべて認証を必要と するような課金制度やペイパービュー制度は崩れ てしまい, 時差無料公開を選択せざるを得ないこ とも十分考えられる。

\section{8. おわりに}

本稿は2005年2月1日の科学技術振興機構での説 明会における尾身の発表にその後の事態の進展を 加筆したものである。NIHの最終決定が2月3日で あったので, 加筆が大幅になったが, この問題の 重要さや学術出版に対する影響が一層明確になっ たのではないかと考えている。オープンアクセス の問題はきわめて重要なので, 今後も事態の進展 を注視し, 分析を加えていきたいと考えている。

\section{9. 追記}

NIHポリシーの実施を5月2日に控え，4月29日に はその実施要綱が公表された 34 。それによれば,研 究者はNIH Manuscript Submission (NIHMS) システム に自分のIDでログインし, 論文の書誌事項や研究 助成者の情報などを入力した後に, 論文の全文と 図表等の追加データをアップロードする。論文や 図表等のファイル形式としては, MS Word, Word Perfect, PDF, Power Point, Excelなどがサポート されている。提出されたファイルからNIHによっ て確認用のPDFが自動作成される。次に研究者は 契約条件とアップロードしたファイルの内容を確 認し, 公開日時を入力する。論文ファイルからNIH が作成したXMLを研究者がPubMed Central上で確 認した後, 指定された公開日に公開される,となっ ている。今後このプロジェクトがどのように研究 者に受け入れられ, 進行するか, 注目していきた い(2005-05-13)。

\section{参考文献}

1）熊谷玲美.オープンアクセス出版. 情報管理. Vol.47, No.1, 2004, p.33-37.

2）時実象一.オープンアクセスの動向. 情報管理. (PLos, Sabo法案, Budapest Open Access Initiativeな ど). Vol.47 No.9, 2004, p.616-624.

3）松下茂. 学術情報流通の新しいトレンド：オープ ンアクセスの現状について．薬学図書館. Vol.49, No.4, 2004, p.252-255.

4）高木和子。世界に広がる機関レポジトリ：現状と 諸問題. 情報管理. Vol.47, No.2, 2005, p.806-817.

5) National Institutes of Health. "Enhanced Public Access to NIH Research Information”. (online), available from < http://grants.nih.gov/grants/guide/ notice-files/NOT-OD-04-064.html > , (accessed 2005-
03-12).

6) National Institutes of Health. "Policy on Enhancing Public Access to Archived Publications Resulting from NIH-Funded Research". (online), available from $<$ http:/grants.nih.gov/grants/guide/notice-files/NOTOD-05-022.html>, (accessed 2005-03-12).

7) "NIH approves free access to publicly funded studies, Chicago Tribune, February 4, 2005”. Open Access News. (online), available from <http://www.earlham. edu/ peters/fos/2005_01_30_fosblogarchive. html\#a110753448040196235>, (accessed 2005-0312).

8) "NIH-funded research to be available free: New policy pushes for posting results online quickly". San 
Francisco Chronicle, February 4, 2005. (online), available from < http://www.sfgate.com/cgi-bin/article/ article $\mathrm{f}=/ \mathrm{c} / \mathrm{a} / 2005 / 02 / 04 / \mathrm{MNG} 8 \mathrm{~TB} 5 \mathrm{~L} 3 \mathrm{~A} 1$. DTL\&type $=$ health $>$

9) "NIH grant Recipients are 'asked' to post data, Washington Post, February 4, 2005”. Open Access News. (online), available from <http:// www.earlham.edu/ peters/fos/2005_01_30_ fosblogarchive.html\#a110753377531381949>, (accessed 2005-03-12).

10) “Science for Free”. Economist. February 10, 2005. (online), available from < http://www.economist.com/ science/displayStory.cfm? story_id $=3644245>$, (accessed 2005-03-12).

11) “The NIH Public Access Policy”. SPARC. (online), available from < http://www.arl.org/sparc/author/ index.html >, (accessed 2005-03-12).

12) Marshall, J. G.; Funk, C. J. "Open letter to Elias Zerhouni, director of NIH”. Medical Library Association. February 11, 2005. (online), available from < http://www.mlanet.org/government/gov_pdf/ zerhouni_nih_proposal.pdf $>$, (accessed 2005-03-12).

13) Baum, Rudy M. "Socialized Science”. Chemical and Engineering News. September 20. Vol.82, No.38, 2004, p.7. (online), available from < http://pubs.acs. org/cen/editor/8238edit.html>, (accessed 2005-03.12).

14) Armstrong, Richard N. Cracking open access. Chemical and Engineering News, October 25. Vol.82, No.43, 2004, p.7, 9, 11.

15) "ACS Broadens Article Access". Chemical and Engineering News. March 7, Vol. 83, No.10, p.10, 2005. (online), available from $<$ http://pubs.acs.org/ cen/news/83/i10/8310acs.html>, (accessed 2005-0312).

16) "American Institute of Physics announces Author Select ${ }^{\mathrm{SM}}$, a new open access initiative for 2005" American Institute of Physics. (online), abvailable from <http://www.aip.org/press_release/ author_select.html $>$, (accessed 2005-03-12).

17) "Enhanced Public Access to NIH Research Information". National academies of Sciencers. (online), available from $<$ http://www 4 . nationalacademies.org/news.nsf/isbn/s09162004? OpenDocument $>$ (accessed 2005-03-12).

18) Cozzarelli, Nicholas R. An open access option for PNAS. Proceedings of the National Academy of Sciences of the United States of America. Vol.101, No.23, p8509. (online), available from <http:// www.pnas.org/cgi/content/full/101/23/8509>, (accessed 2005-03-12).

19) “Not-for-profit Publishers Call New NIH Rule Missed Opportunity: Scientific societies worry about burden in researchers and waste of research dollars". (online), available from < http://www.dcprinciples.org/ nih_rule.htm $>$, (accessed 2005-03-12).

20) "Enhanced Public Access to NIH Research Information:A response from Elsevier, November 15, 2004". Elsevier. (online), available from < http:// www.elsevier.com/authored_news/corporate/images/ NIH.pdf>, (accessed 2005-03-12).

21) "Nature Publishing Group announces change to selfarchiving policy”. January 10, 2005. Nature Publishing Group. (online), available from <http:// npg.nature.com/pdf/archiving.doc $>$, (accessed 200503-12).

22) "EMBO and NPG announce a new online publication: Molecular Systems Biology”. 7 September, 2004. Macmillan. (online), available from <http:// www.macmillan.com/07092004emboandnpg.asp >, (accessed 2005-03-12).

23) Science Magazine. "License to Publish Information for Authors" (online), available from <http://www. sciencemag.org/feature/contribinfo/prep/lic_info. pdf $>$, (accessed 2005-03-31)

24) "Statement of the Association of American Publishers/Professional and Scholarly Publishing Division (AAP/PSP) Regarding the National Institutes of Health's Public Access Policy”. March 2, 2005. Mailing List SPARK-OAForum@arl.org Message\#1723. (online), available from < https:// $\mathrm{mx}$ 2.arl.org/Lists/SPARC-OAForum/Message/ 1723.html>, (accessed 2005-03-12).

25) House of Commons Science and Technology Committee. "Scientific Publications: Free for all?". July 7, 2004.(online), available from < http://www. publications.parliament.uk/pa/cm200304/cmselect/ cmsctech/399/39902.htm > (accessed 2005-03-12).

26) "Appendix 1: Response from the Government". Responses to the Committee's Tenth Report, Session 2003-04, Scientific Publications: Free for all? : Fourteenth Report of Session 2003-04. (online), available from < http://www.publications.parliament. $\mathrm{uk} / \mathrm{pa} / \mathrm{cm} 200304 / \mathrm{cmselect} / \mathrm{cmsctech} / 1200 / 1200$.pdf $>$, (accessed 2005-03-12).

27) House of Commons Science and Technology Committee. Responses to the Committee's Tenth Report, Session 2003-04, Scientific Publications: Free for all? : Fourteenth Report of Session 2003-04. (online), available from <http://www.publications. 
parliament.uk/pa/cm200304/cmselect/cmsctech/1200/ 1200.pdf >, (accessed 2005-03-12).

28) "Appendix 1: Response from the Government". Responses to the Committee's Tenth Report, Session 2003-04, Scientific Publications:Free for all?: Responses to the Committee's 14th Report of Session 2003-04, Third Special Report of Session 2004-05, 26 January, 2005. (online), available from <http:// www.publications.parliament.uk/pa/cm200405/ cmselect/cmsctech/249/249.pdf>, (accessed 2005-0312).

29) "Wellcome Trust response to report on scientific publishing”. 20 July, 2004.(online), available from $<$ http://www.wellcome.ac.uk/ doc_WTD005969.html>, (accessed 2005-03-12).

30) Terry, R. Funding the Way to Open Access. PLoS Biol Vol.3, No.3, 2005, e97. (online), available from < http:/ /biology.plosjournals.org/perlserv/?request = getdocument\&doi=10.1371/journal.pbio.0030097> , (accessed 2005-04-20).
31) "Wellcome Trust and National Library of Medicine in talksfor worldwide open access archive” (online), available from < http://www.wellcome.ac.uk/ doc_WTX022826.html>, (accessed 2005. 3. 12).

32) "Archive of medical journals to go online: An archive of medical journals, some dating back more than 125 years, will be made freely available on the Internet". 28 June, 2004. Wellcome Trust. (online), available from < http://library.wellcome.ac.uk/doc_wtx017073. html $>$ (accessed 2005-03-12).

33) "CERN Confirms commitment to Open Access". CERN Press release. (online), available from <http:// info.web.cern.ch/Press/PressReleases/Releases2005/ PR04.05E.html>, (accessed 2005-04-04).

34) "Implementation of Policy on Enhancing Public Access to Archived Publications Resulting from NIH-Funded Research". (online), available from < http://grants. nih.gov/grants/guide/notice-files/NOT-OD-05-045. html>, (accessed 2005-05-13).

\section{参考 Web サイト}

arXiv.org e-Print archive $<$ http://arxiv.org/ $>$

ACS Publications < http://pubs.acs.org/>

Berlin Declaration on Open Access to Knowledge in the Sciences and Humanities <http://www.zim.mpg.de/ openaccess-berlin/>

Berlin 2 Open Access: Steps Toward Implementation of the Berlin Declaration on Open Access to Knowledge in the Sciences and Humanities < http://www.zim.mpg.de/openaccess-cern/>

Berlin 3 Open Access: Progress in Implementing the Berlin Declaration on Open Access to Knowledge in the Sciences and Humanities < http://www.eprints.org/berlin3/>

Bethesda Statement on Open Access Publishing < http://www.earlham.edu/ peters/fos/bethesda.htm >

BioMedCentral < http://www.biomedcentral.com/ $>$

Budapest Open Access Initiative (BOAI) <http://www.soros.org/openaccess/help.shtml >

Directory of Open Access Journals (DOAJ) <http://www.doaj.org/ $>$

Directory of Open Access Repositories (DOAR) <http://www.opendoar.org/>

DSpace < http://www.dspace.org/>

HighWire Press <http://highwire.stanford.edu/>

J-STAGE <http://www.jstage.jst.go.jp/>

NIH Manuscript Submission (NIHMS) < http://www.nihms.nih.gov/>

Online Journals from the RSC <http://www.rsc.org/is/journals/current/ejs.htm>

Open Archives Initiative <http://www.openarchives.org/>

Public Access, NIH <http://www.nih.gov/about/publicaccess/>

Public Library of Science < http://www.plos.org/>

Publisher copyright policies \& self-archiving < http://www.sherpa.ac.uk/romeo.php $>$

PubMed Central <http://www.pubmedcentral.org/>

SPARC < http://www.arl.org/sparc/>

Washington DC Principles for Free Access to Science <http://www.dcprinciples.org/> 